\title{
Tracer gas decay test in Net-Zero Energy Residential Test Facility
}

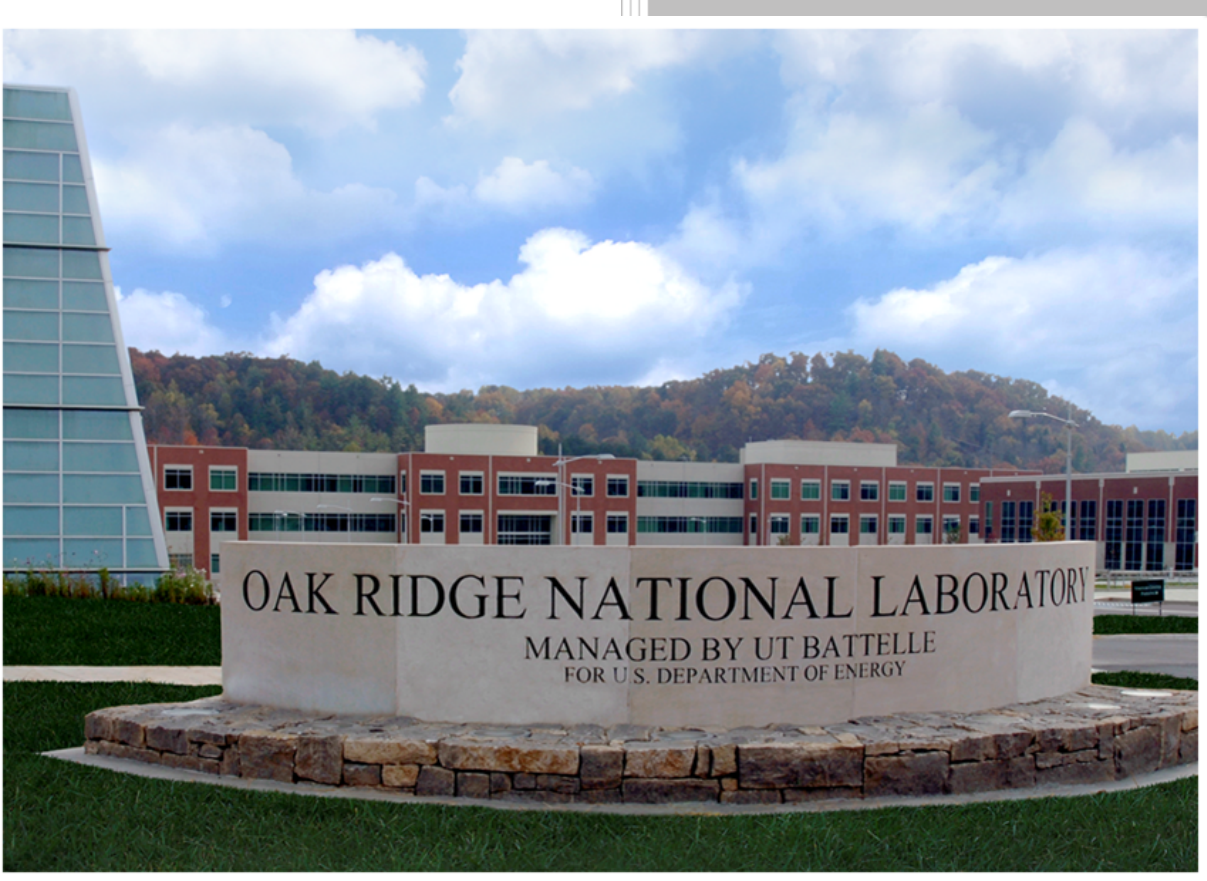

Lisa Ng, Ph.D.

Piljae Im, Ph.D.

Yeonjin Bae, Ph.D.

June 30, 2020 


\title{
DOCUMENT AVAILABILITY
}

Reports produced after January 1, 1996, are generally available free via US Department of Energy (DOE) SciTech Connect.

Website http://www.osti.gov/scitech/

Reports produced before January 1, 1996, may be purchased by members of the public from the following source:

\author{
National Technical Information Service \\ 5285 Port Royal Road \\ Springfield, VA 22161 \\ Telephone 703-605-6000 (1-800-553-6847) \\ TDD 703-487-4639 \\ Fax 703-605-6900 \\ E-mail info@ntis.gov \\ Website http://www.ntis.gov/help/ordermethods.aspx
}

Reports are available to DOE employees, DOE contractors, Energy Technology Data Exchange representatives, and International Nuclear Information System representatives from the following source:

Office of Scientific and Technical Information

PO Box 62

Oak Ridge, TN 37831

Telephone 865-576-8401

Fax 865-576-5728

E-mail reports@osti.gov

Website http://www.osti.gov/contact.html

This report was prepared as an account of work sponsored by an agency of the United States Government. Neither the United States Government nor any agency thereof, nor any of their employees, makes any warranty, express or implied, or assumes any legal liability or responsibility for the accuracy, completeness, or usefulness of any information, apparatus, product, or process disclosed, or represents that its use would not infringe privately owned rights. Reference herein to any specific commercial product, process, or service by trade name, trademark, manufacturer, or otherwise, does not necessarily constitute or imply its endorsement, recommendation, or favoring by the United States Government or any agency thereof. The views and opinions of authors expressed herein do not necessarily state or reflect those of the United States Government or any agency thereof. 
Energy and Transportation Science Division

\title{
Tracer gas test in Net-Zero Energy Residential Test Facility
}

\author{
Lisa Ng, Ph.D. \\ Piljae Im, Ph.D. \\ Yeonjin Bae, Ph.D.
}

\author{
Prepared by \\ OAK RIDGE NATIONAL LABORATORY \\ Oak Ridge, TN 37831-6283 \\ managed by \\ UT-BATTELLE, LLC \\ for the \\ US DEPARTMENT OF ENERGY \\ under contract DE-AC05-00OR22725
}




\section{Net-Zero Energy Residential Test Facility}

The Net-Zero Energy Residential Test Facility (NZERTF) at NIST was built in 2012 to support the development and adoption of cost-effective net-zero energy designs, technologies, and construction methods (Fig. 1). It is two-story, and has four bedrooms, three bathrooms, and an open living room, dining room, and kitchen space. The NZERTF also has a basement and attic, both located within the conditioned space because the thermal and air-moisture barriers encompass the basement walls and attic roof. Transfer grilles link the living spaces to these two zones. The central heating and cooling system includes an air-toair heat pump, which delivers air to the basement, first and second floors. The heat pump has a cooling capacity of $7.6 \mathrm{~kW}$ and a heating capacity of $7.8 \mathrm{~kW}$. The indoor unit is in the basement and ductwork runs along the basement ceiling. A balanced heat recovery ventilator (HRV) is installed in the basement and has its own dedicated ductwork. The HRV supplies $47 \mathrm{~L} / \mathrm{s}$ of outdoor air to the house, with supplies on the first floor (in the kitchen/dining area) and in each of the three second-floor bedrooms. Air from the first-floor bathroom and both second-floor bathrooms is returned to the HRV before being exhausted, though the HRV was turned off during the tests. The house also has a range hood exhaust and a clothes dryer exhaust, both of which were turned off for the tests. The temperature of the house was measured and the operation of the space conditioning system, including its recirculating air distribution fan, were controlled by a commercially available thermostat. Table 1 summarizes the characteristics of the NZERTF. Additional design, construction, equipment, and energy performance details for the NZERTF can be found in Refs. [1$3]$.

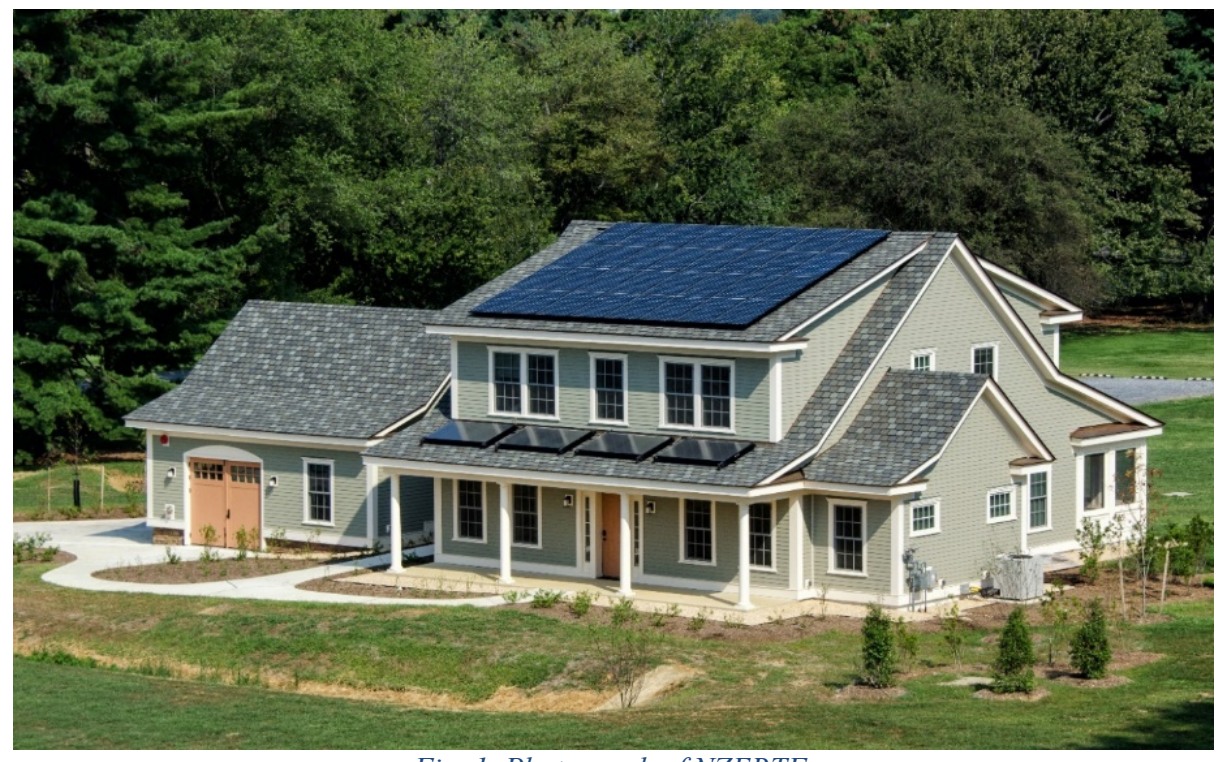

Fig. 1. Photograph of NZERTF. 
Table 1. Characteristics of NZERTF.

\begin{tabular}{cc}
\hline Building characteristics & NZERTF \\
\hline Year of construction & 2012 \\
\hline Floor area $\left(\mathrm{m}^{2}\right)$ & 245 (habitable area) \\
& 490 (all floors) \\
\hline Building volume $\left(\mathrm{m}^{3}\right)$ & 1301 (all floors) \\
\hline Stories & 3 above ground, includes attic \\
\hline Height $(\mathrm{m})$ & 6.3 \\
\hline Exterior surface area, above grade $\left(\mathrm{m}^{2}\right)$ & 367 \\
\hline$E L A$ at 4 Pa $\left(\mathrm{cm}^{2}\right)$ & 137 \\
(from blower door test) & Air-to-air heat pump \\
Heating/Cooling system & $7.6 \mathrm{~kW}$ cooling capacity \\
& $7.8 \mathrm{~kW}$ heating capacity \\
\hline
\end{tabular}

\section{Measurements}

Tracer gas decay tests were conducted to measure decay rates in the NZERTF under the test conditions in Table 2. The mechanical ventilation system was off during the tests, as well as the dryer and range hood exhausts.

Table 2. Summary of test conditions.

\begin{tabular}{llll}
\hline Test code & Description & Testing dates & Internal loads \\
$\begin{array}{l}\text { Test HEQ- } \\
\text { N001 }\end{array}$ & Base Case (72F Setpoint) & Jan 12-18 & None \\
$\begin{array}{l}\text { Test HEQ- } \\
\text { N002 } \\
\text { Test HEQ- } \\
\text { N003 }\end{array}$ & $\begin{array}{l}\text { Scheduled Internal Heat Gains } \\
\text { Demand Response (DR)-Enabled } \\
\text { Thermostat }\end{array}$ & Jan 3-8 & $\begin{array}{l}\text { Saturday } \\
\text { schedule }\end{array}$ \\
\hline
\end{tabular}

The tracer gas decay tests complied with ASTM E741-11 [4], with sulfur hexafluoride (SF6) automatically injected every 72 hours at specified time intervals into the three bedrooms on the second floor and the kitchen on the first floor. Mixing fans were placed in the Living Room and at the top of the stairs to encourage mixing of air. The tracer gas was sampled in six locations (Master bedroom, Bedroom 3, Living Room, Basement, Attic, and Outside) in the NZERTF (Fig. 3) at 30 s intervals with a photoacoustic infrared sampler. This instrument has a measurement range of $3.6 \mathrm{mg} / \mathrm{m} 3$ to $35.8 \mathrm{mg} / \mathrm{m} 3(0.6 \mathrm{ppmv}$ to $6 \mathrm{ppmv})$, and the manufacturer's reported accuracy is $5 \%$ and its rated repeatability is within $1 \%$. 


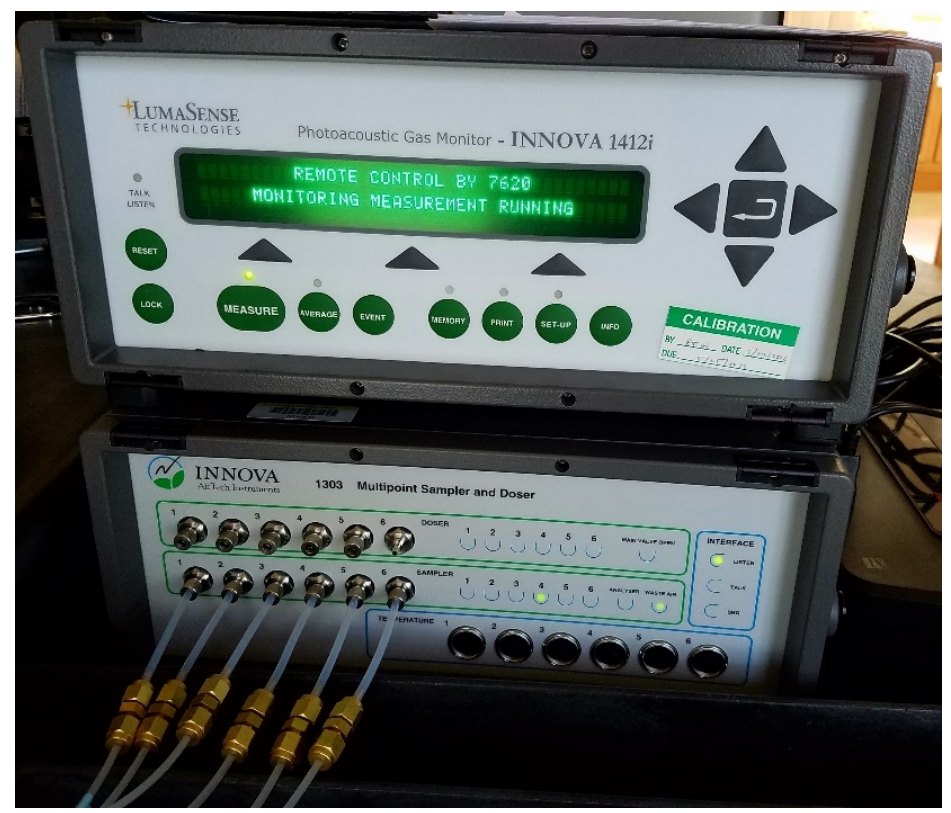

Fig. 2. Photoacoustic infrared sampler

During the tests, the basement and attic doors were always closed. Thus, the decay rates measured account for infiltration through the building envelope as well as any dilution (or addition) of SF6 from the basement or attic.

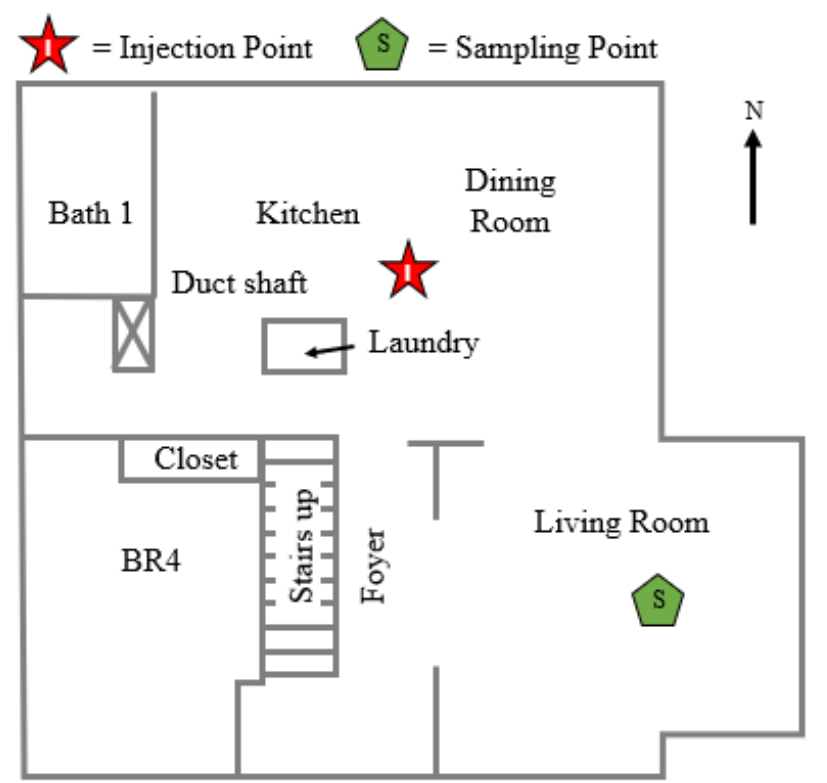

First floor

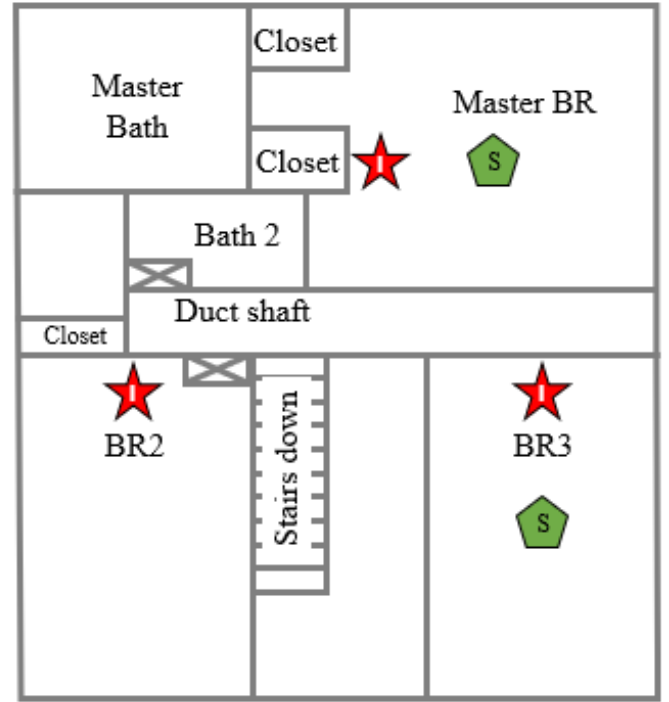

Second floor

Fig. 3. SF ${ }_{6}$ injection/sampling locations in NZERTF (sampling locations in Basement, Attic, and Outside not shown).

A summary of the measured decay rates is provided in Table 3The average outdoor temperature was lower than the average indoor temperature throughout all three tests. The infiltration increases as the average outdoor temperature decreases relative to the average indoor temperature. An increase in the average wind speed resulted in an increase in infiltration. The infiltration remained low throughout the series of tests. 
Table 3. The average outdoor temperature was lower than the average indoor temperature throughout all three tests. The infiltration increases as the average outdoor temperature decreases relative to the average indoor temperature. An increase in the average wind speed resulted in an increase in infiltration. The infiltration remained low throughout the series of tests.

Table 3. Measured decay rates for NZERTF.

\begin{tabular}{ccccc}
\hline Test code & $\begin{array}{c}\text { Average } \boldsymbol{T}_{\text {out }}-\boldsymbol{T}_{\text {in }} \\
\left({ }^{\circ} \mathbf{C}\right)\end{array}$ & $\begin{array}{c}\text { Average } \boldsymbol{W}_{\mathbf{s}} \\
(\mathbf{m} / \mathbf{s})\end{array}$ & $\begin{array}{c}\text { Infiltration } \\
(\mathbf{1} / \mathbf{h})\end{array}$ & $\begin{array}{c}\mathbf{9 5} \text { \% confidence } \\
\text { interval (1/h) }\end{array}$ \\
\hline Test HEQ-N001 & & & & \\
Decay 1 & -9.8 & 2.9 & 0.0339 & 0.0004 \\
Decay 2 & -13.7 & 2.3 & 0.0275 & 0.0002 \\
Decay 3 & -23.6 & 3.2 & 0.0433 & 0.0013 \\
Test HEQ-N002 & & & & \\
Decay 4 & -12.3 & 2.1 & 0.0246 & 0.0002 \\
Decay 5 & -18.6 & 2.4 & 0.0319 & 0.0002 \\
Decay 6 & -20.9 & 3.0 & 0.0386 & 0.0004 \\
Test HEQ-N003 & & & & \\
Decay 7 & -18.9 & 1.3 & 0.0313 & 0.0006 \\
Decay 8 & -10.8 & 2.2 & 0.0250 & 0.0003 \\
Decay 9 & -15.8 & 2.3 & 0.0314 & 0.0004 \\
\hline
\end{tabular}

\section{REFERENCES}

[1] Pettit B, Gates C, Fanney AH, Healy W (2014) Design Challenges of the NIST Net-Zero Energy Residential Test Facility. (National Institute of Standards and Technology, Gaithersburg, MD).

[2] Fanney AH, Payne V, Ullah T, Ng L, Boyd M, Omar F, Davis M, Skye H, Dougherty B, Polidoro B, Healy W, Kneifel J, Pettit B (2015) Net-zero and beyond! Design and performance of NIST's Net-Zero Energy Residential Test Facility. Energ Buildings 101(0):95-109. https://doi.org/http://dx.doi.org/10.1016/j.enbuild.2015.05.002

[3] Fanney H, Healy WM, Payne V, Kneifel J, Ng L, Dougherty BP, Ullah T, Omar F (2017) Small Changes Yield Large results at NIST's Net-Zero Energy Residentail Test Facility. Journal of Solar Energy Engineering. https://doi.org/10.1115/1.4037815

[4] ASTM (2011)-ASTM E741-11 Standard Test Method for Determining Air Change in a Single Zone by Means of a Tracer Gas Dilution (American Society for Testing and Materials, West Conshohocken, PA). 